UDC 634.13-115.1

Original research paper

doi: 10.5937/AASer1846157P

Acta Agriculturae Serbica, Vol. XXIII, 46 (2018); 157-165

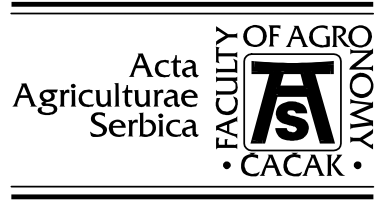

\title{
Economic analysis of pear orchard establishment
}

\author{
Gorica Paunović ${ }^{1}$, Biljana Veljković ${ }^{1}$, Radmila Ilić ${ }^{1}$, Ljiljana \\ Bošković-Rakočević ${ }^{1}$ \\ ${ }^{1}$ University of Kragujevac, Faculty of Agronomy, Čačak, Serbia \\ *Corresponding author: radmila.nikolic@kg.ac.rs
}

\begin{abstract}
As a fruit crop, the pear is preferably grown and esteemed for its high utility value. Over recent decades, there have been great fluctuations in both quantity and quality of the pear fruit for a variety of reasons (obsolete growing technology, cultivar diversity, increased fire blight attacks, market instability, etc.). Given the favourable environmental conditions in Serbia and pear fruit shortage on domestic and foreign markets, producers' interest in pear production has increased in the last several years. The economic performance of a pear orchard is largely dependent on market conditions and pear marketing possibilities. Establishing a pear orchard requires a comprehensive analysis of agroeconomic conditions which govern both the choice of cultivars and orchard size. Therefore, the objective of this study was to analyse pear orchard establishment costs. Two cultivars were used i.e. 'Williams' and 'Santa Maria'. The results of the agroeconomic analysis show that the investment costs of establishing a 1 ha orchard amount to $€ 8,975.75$. Orchard management costs are $€ 2,020.25$ in the first year, $€ 1,803.25$ in the second year and $€ 3,026.00$ in the third year. Total investment costs associated with orchard establishment and management during the first three years are $€$ 18,510.25. Management costs for a fully productive orchard are $€ 4,657.00$. The return on investment, along with profit, is achieved in the fifth year. If the intensive orchard produced a yield higher by $35 \%$ than the average yield projections, as typical of highdensity production systems, the return on investment would be achieved in the fourth year.
\end{abstract}

Keywords: Pear, Economic analysis, Costs, Profit. 


\section{Introduction}

Establishing a pear plantation using modern production technology is a major investment which requires a detailed organisational and economic analysis of factors such as choice of location, land preparation, choice of cultivar and training system, high-quality planting material, modern machinery, use of cultural practices and organisation of harvest, sale and placement on the market. The analysis also involves the evaluation of economic and market conditions which will affect the volume of production and choice of cultivars. Market conditions and pear marketing possibilities largely govern the economic performance of a pear orchard. Sales possibilities are based on the product demand by large consumer centres in the country and abroad, with due consideration given to the local market. The choice of cultivars is dependent on market demand and market capacity, with respect to both fresh consumption and processing, and is generally oriented to cultivars produced for export as fresh produce and for industrial processing.

This study focused on the economic analysis of pear orchard establishment costs, and on the related calculation of economic parameters i.e. investment expenses and expected revenue.

\section{Material and Methods}

Research was conducted in a commercial pear orchard located in the Trbušani suburban area of Čačak (Latitude $43^{\circ} 55^{\prime} 17^{\prime \prime} \mathrm{N}$; Longitude $20^{\circ} 19^{\prime} 08^{\prime \prime}$ $\mathrm{E}$; Altitude $256 \mathrm{~m}$ ), characterised by flat terrain with no pronounced exposure. The orchard was established in autumn i.e. November 2009, using the producer's own financial resources. The nursery trees used to establish the orchard were bench-grafted in March of the same year and grown in the producer's own nursery until they were transferred to their permanent location. The BA 29 clone of Provence (Angers) quince was used as the rootstock. Plant spacing was $4 \mathrm{~m}$ between rows and $1.5 \mathrm{~m}$ within rows, which gave a plant density of 1,667 plants $\mathrm{ha}^{-1}$. Pear trees were grown in a high-density system, and trained to spindle bush. In this high-intensity orchard, modern growing technology, also including drip irrigation, was used. Two pear cultivars were planted i.e. 'Williams' and 'Santa Maria', which exhibit fruit maturity in the second half of August.

To perform an economic analysis, the analytical calculations method was used to calculate production expenses, planned revenue and profitability of the investment. Total revenue was calculated on a cumulative basis, starting from the years of low fruit yield, as were total expenses for the orchard establishment period until full productivity, which ensured a return on investment and profitability. 


\section{Results and Discussion}

When establishing the high-intensity pear orchard on 1 ha of land, all production parameters were recorded, costs were calculated, and calculations were provided. Costs of primary tillage and soil agromelioration treatment were based on total costs of labour, machinery, and materials used for fertilization and soil amendment (manure, mineral fertilisers, green manure and $\mathrm{CaCO}_{3}$ used for liming), and amounted to €2,685.00. Labour costs were calculated based on the rate of daywork, and machinery costs were based on the hourly rate (Table1).

Labour throughout the growing season is an important factor which affects the cost-effectiveness of pear production. The potential to meet labour requirements is a major determinant of both orchard size and choice of cultivars. Labour costs at a daywork rate of $€ 20$ were $€ 670.00$, and machinery costs totalled $€ 480.00$.

Table 1. Costs of primary tillage and agromelioration treatment for a 1 ha pear orchard

\begin{tabular}{|l|l|r|}
\hline Costs of primary tillage and & A. Labour & 126.00 \\
\cline { 2 - 3 } $\begin{array}{l}\text { land preparation for planting } \\
\text { (in } € \text { ) }\end{array}$ & B. Machinery & $1,760.00$ \\
\cline { 2 - 3 } & C. Material & 799.00 \\
\cline { 2 - 3 } & & $2,685.00$ \\
\hline
\end{tabular}

As reported by Glišić et al. (2014), machinery costs for apricot orchard establishment were $€ 740.00$. Machinery costs include costs of land preparation for planting and material transport costs.

Drip irrigation provides the supply of water and nutrients at appropriate amounts, while minimising water losses through evapotranspiration (over 50\% reduction) (Trajković and Milanović, 2012). This type of irrigation is highly costeffective as it reduces the amount of water needed for irrigation and makes savings in labour used for irrigation, fertilisation, and system maintenance and operation. The cost of the drip irrigation system installed in the orchard and accessories was $€ 4,000.00 \mathrm{ha}^{-1}$. The cost of the material used for planting the 1 ha pear orchard (nursery trees, mineral fertilisers and irrigation system) totalled $€ 7,825.75$ (Table2). Milić et al. (2013) provided establishment cost calculations for an apple orchard. Costs were $€ 37,673.94$, but they also included hail netting, fencing and frost protection costs. As calculated by Glišić et al. (2014), establishment costs for an apricot orchard, excluding irrigation and hail netting, under similar agroenvironmental conditions were $€ 2,980.00$. Also, establishment costs for a 1 ha plum orchard were $€ 7,729.00$ (Milosevic et al., 2008). Therefore, establishment costs for a pear orchard are significantly higher than those for apricot and plum orchards. 
Table 2. Establishment cost calculations for a 1 ha pear orchard

\begin{tabular}{|c|c|c|c|c|}
\hline Type of cost & $\begin{array}{c}\text { Unit of } \\
\text { measurement }\end{array}$ & $\begin{array}{c}\text { Requirement per } 1 \\
\text { ha }\end{array}$ & $\begin{array}{l}\text { Rate per unit of } \\
\text { measurement }(€)\end{array}$ & $\begin{array}{l}\text { Cost }(€) \\
\text { per } 1 \text { ha }\end{array}$ \\
\hline \multicolumn{5}{|c|}{ A. LABOUR COSTS } \\
\hline $\begin{array}{l}\text { Preparation, loading } \\
\text { and unloading of } \\
\text { markers }\end{array}$ & work day & 3.0 & 20.00 & 60.00 \\
\hline $\begin{array}{l}\text { Measuring and } \\
\text { marking }\end{array}$ & work day & 5.0 & 20.00 & 100.00 \\
\hline $\begin{array}{l}\text { Loading, unloading } \\
\text { and heeling-in of } \\
\text { nursery trees }\end{array}$ & work day & 2.2 & 20.00 & 44.00 \\
\hline Loading of manure & work day & 0.8 & 20.00 & 16.00 \\
\hline $\begin{array}{l}\text { Loading and } \\
\text { unloading of mineral } \\
\text { fertilisers }\end{array}$ & work day & 0.2 & 20.00 & 10.00 \\
\hline Digging of holes & work day & 9.0 & 20.00 & 180.00 \\
\hline $\begin{array}{l}\text { Planting nursery trees } \\
\text { and manuring }\end{array}$ & work day & 10.0 & 20.00 & 200.00 \\
\hline $\begin{array}{l}\text { Watering of planted } \\
\text { nursery trees }\end{array}$ & work day & 3.0 & 20.00 & 60.00 \\
\hline & & & & $\begin{array}{r}\text { TOTAL: } \\
\mathbf{6 7 0 . 0 0} \\
\end{array}$ \\
\hline \multicolumn{5}{|c|}{ B. MACHINERY COSTS } \\
\hline $\begin{array}{l}\text { Transport of markers } \\
\text { and nursery trees }\end{array}$ & hour/tractor & 3 & 20.00 & 60.00 \\
\hline Transport of manure & hour/tractor & 8 & 20.00 & 160.00 \\
\hline $\begin{array}{l}\text { Transport of mineral } \\
\text { fertilisers }\end{array}$ & hour/tractor & 3 & 20.00 & 60.00 \\
\hline $\begin{array}{l}\text { Transport of water for } \\
\text { watering }\end{array}$ & hour/tractor & 10 & 20.00 & 200.00 \\
\hline \multirow{2}{*}{\multicolumn{5}{|c|}{ TOTAL: $\mathbf{4 8 0 . 0 0}$}} \\
\hline & & & & \\
\hline Pear nursery trees & Pc. & $1,667.00$ & 2.25 & $3,750.75$ \\
\hline $\begin{array}{l}\text { Mineral fertiliser } \\
\text { (NPK) }\end{array}$ & $\mathrm{kg}$ & 150 & 0.50 & 75.00 \\
\hline Drip irrigation system & ha & 1 & $4,000.00$ & $4,000.00$ \\
\hline \multicolumn{5}{|c|}{ TOTAL: $7,825.75$} \\
\hline \multirow{4}{*}{$\operatorname{cosTS} A+B+C$} & \multicolumn{2}{|l|}{ A. Labour costs } & \multicolumn{2}{|c|}{670.00} \\
\hline & \multirow{2}{*}{\multicolumn{2}{|c|}{$\begin{array}{l}\text { B. Machinery costs } \\
\text { C. Material costs }\end{array}$}} & \multicolumn{2}{|r|}{480.00} \\
\hline & & & \multirow{2}{*}{\multicolumn{2}{|c|}{$\begin{array}{l}7,825.75 \\
\mathbf{8 , 9 7 5 . 7 5}\end{array}$}} \\
\hline & \multicolumn{2}{|l|}{ C. Material costs } & & \\
\hline
\end{tabular}

For pear trees to come into crop as early as possible, proper and timely cultural operations (soil tillage, fertilisation, irrigation, and pest and disease control) and tree management practices (pruning for crown training purposes) are required. Well-tended trees will come to fruit early, have a longer life span, and produce high yields of good-quality fruit (Mratinić, 2012). 
In the spring of the first year after planting, soil tillage was performed to improve the structure of the soil compacted during planting. For normal growth, development and fruiting, pear trees should have sufficient amounts of nitrogen, potassium and phosphorus during the growing season. The rate and type of fertilisers are generally determined based on soil chemical analysis. In the first year after planting, the orchard was irrigated with $10 \mathrm{l}$ water per tree. When performing irrigation, attention should be paid to critical periods: after petal fall, after the June fruit drop, during fruit development and during the differentiation of buds for the following year (Milošević, 1997). In the first year, young pear trees were protected from pests (leaf aphids, pear psylla) and disease agents (pear scab, fire blight). During the autumn, the nursery trees that did not take root for a variety of reasons were replaced with new ones.

Table 3. Cumulative costs across years for establishing a 1 ha pear orchard

\begin{tabular}{|l|l|c|}
\hline $\begin{array}{l}\text { Item } \\
\text { No. }\end{array}$ & \multicolumn{1}{|c|}{ Type of cost } & Total (€) \\
\hline 1. & Primary tillage and agromelioration treatment & $2,685.00$ \\
\hline 2. & Costs of establishment (planting) & $8,975.75$ \\
\hline 3. & Management costs in year 1 & $2,020.25$ \\
\hline 4. & Management costs in year 2 & $1,803.25$ \\
\hline 5. & Management costs in year 3 & $3,026.00$ \\
\hline 6. & Total investment per 1 ha & $18,510.25$ \\
\hline
\end{tabular}

In the years after planting, 3 to 4 cultivation or tillage operations were performed to prevent weed development, crush soil crust and prevent soil moisture loss. In the autumn, the soil was treated with NPK containing increased levels of phosphorus and potassium; in the spring, CAN was incorporated. Depending on agroenvironmental conditions, disease and pest control was used. Management costs for the young pear orchard during the first three years (Table 3 ) totalled $€ 6,849.5$. Along with total establishment costs, total investment costs in the third year amounted to €18,510.25 (Table 3).

At full productivity, all agricultural practices necessary for pear production were used. Production parameters and related costs are given in Table 4. The amount of work and number of seasonal workers were highest during pruning and harvest. A total of 55 work days were required for the harvesting operation, the cost of which amounted to $€ 1,100$ (Table 4). 
Table 4. Management cost calculations for a fully productive pear orchard

\begin{tabular}{|c|c|c|c|c|}
\hline Type of cost & $\begin{array}{c}\text { Unit of } \\
\text { measurement }\end{array}$ & $\begin{array}{l}\text { Requirement per } 1 \\
\text { ha }\end{array}$ & $\begin{array}{l}\text { Price per unit of } \\
\text { measurement }(€)\end{array}$ & $\begin{array}{l}\text { Cost }(€) \\
\text { per } 1 \text { ha }\end{array}$ \\
\hline \multicolumn{5}{|c|}{ A. LABOUR COSTS } \\
\hline $\begin{array}{l}\text { Pruning for fruit } \\
\text { bearing (winter } \\
\text { pruning) }\end{array}$ & work day & 15 & 20.00 & 300.00 \\
\hline $\begin{array}{l}\text { Collection and } \\
\text { removal of } \\
\text { branches }\end{array}$ & work day & 2.5 & 20.00 & 50.00 \\
\hline $\begin{array}{l}\text { Transport of water } \\
\text { for spraying } \\
\text { operations }\end{array}$ & work day & 1.5 & 20.00 & 30.00 \\
\hline $\begin{array}{l}\text { Winter and } 8 \\
\text { summer spraying } \\
\text { operations }\end{array}$ & work day & 1.6 & 20.00 & 32.00 \\
\hline Summer pruning & work day & 7.0 & 20,00 & 140.00 \\
\hline $\begin{array}{l}\text { Herbicide spray } \\
\text { (2 applications) }\end{array}$ & work day & 1.5 & 20.00 & 30.00 \\
\hline $\begin{array}{l}\text { Loading, transport } \\
\text { and unloading of } \\
\text { packaging and fruit }\end{array}$ & work day & 5 & 20.00 & 100.00 \\
\hline Fruit harvest & work day & 55 & 20.00 & $1,100.00$ \\
\hline \multirow{2}{*}{\multicolumn{5}{|c|}{ TOTAL: 1,782.00 }} \\
\hline & & & & \\
\hline $\begin{array}{l}\text { Transport and } \\
\text { spreading of } \\
\text { mineral fertiliser }\end{array}$ & hour/tractor & 10 & 20.00 & 200.00 \\
\hline $\begin{array}{l}\text { Winter and } 8 \\
\text { summer spraying } \\
\text { operations }\end{array}$ & hour/tractor & 16 & 20.00 & 320.00 \\
\hline Herbicide spray & hour/tractor & 8 & 20.00 & 160.00 \\
\hline $\begin{array}{l}\text { Collection and } \\
\text { removal of } \\
\text { branches }\end{array}$ & hour/tractor & 8 & 20.00 & 160.00 \\
\hline $\begin{array}{l}\text { Transport of } \\
\text { packaging and fruit }\end{array}$ & hour/tractor & 20 & 20.00 & 400.00 \\
\hline $\begin{array}{l}\text { Transport of water } \\
\text { for spraying } \\
\text { operations }\end{array}$ & hour/tractor & 8 & 20.00 & 160.00 \\
\hline $\begin{array}{l}\text { Cultivation and } \\
\text { tillage }\end{array}$ & hour/tractor & 15 & 20.00 & 300.00 \\
\hline \multicolumn{5}{|c|}{ TOTAL: $\mathbf{1 , 7 0 0 . 0 0}$} \\
\hline \multicolumn{5}{|c|}{ C. MATERIAL COSTS } \\
\hline $\begin{array}{l}\text { Nitrogen fertiliser } \\
\text { (CAN) }\end{array}$ & $\mathrm{kg}$ & 500 & 0.35 & 175.00 \\
\hline $\begin{array}{l}\text { Complex fertiliser } \\
\text { (NPK) }\end{array}$ & $\mathrm{kg}$ & 1000 & 0.50 & 500.00 \\
\hline
\end{tabular}




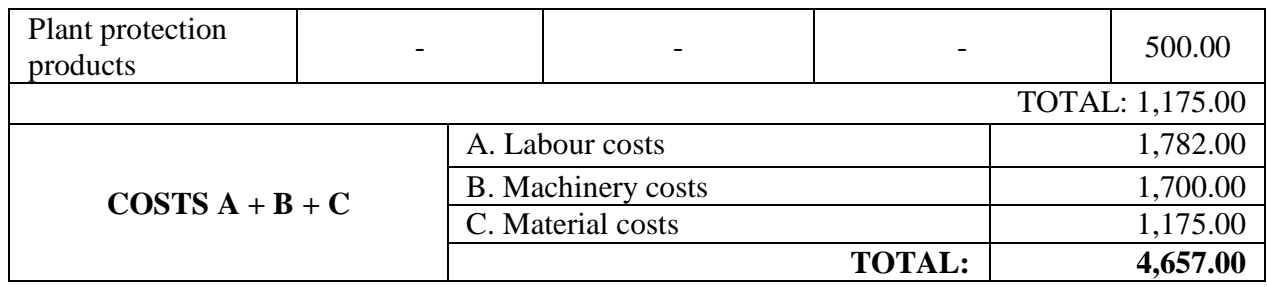

Harvesting is the final operation in fruit production which may impact the financial performance of an orchard. Therefore, it is necessary to determine the optimum harvest date (mean date around which the crop must be harvested), depending on the intended use of the fruit. Fruits for fresh consumption must be harvested at technological maturity. Late harvest significantly reduces the transportability and cold storage capacity of fruit. Pear yield in the second year after planting was about $2 \mathrm{~kg}$ per tree. The yield of the orchard consisting of 1,667 trees/ ha was 3,334 kg. In the third year, yield was about $7 \mathrm{~kg}$ per tree or 11,669 per hectare. Fruit yield was low until the third year, and full productivity started in the fourth year, with $17 \mathrm{~kg}$ per tree. Yield at full productivity was $28,339 \mathrm{~kg}$ per hectare. It is noteworthy that, in years favourable for pear trees, fruit yields in high-density orchards exceeded $20 \mathrm{~kg}$ per tree or $30 \mathrm{t} \mathrm{ha}^{-1}$.

Pear fruits were placed on wholesale and local markets, and were also sold for export in an organised manner. The average farmgate price for first-class pears was $0.5 € / \mathrm{kg}$. Fruits that did not meet quality standards for fresh consumption were sold to processing companies to be processed mostly into brandy. Swisslion-Takovo, based in Gornji Milanovac, is a large processing company in this region, which processes 'William' pears into a brandy of the same name, and purchases pear fruit at a price of $0.25-0.30 € / \mathrm{kg}$.

Table 5. Recapitulation of revenue and expenses in pear production

\begin{tabular}{|c|c|c|c|c|c|}
\hline & \multicolumn{2}{|c|}{ Expenses, Costs (€/ha) } & \multicolumn{2}{|c|}{ Revenue (€/ha) } & \multirow{2}{*}{$\begin{array}{c}\text { Balances } \\
(€ / h a) \\
\text { B-A }\end{array}$} \\
\hline & $\begin{array}{c}\text { In the } \\
\text { particular } \\
\text { year }\end{array}$ & $\begin{array}{c}\text { Cumulative } \\
\text { (A) }\end{array}$ & $\begin{array}{c}\text { In the } \\
\text { particular } \\
\text { year }\end{array}$ & $\begin{array}{l}\text { Cumulative } \\
\text { (B) }\end{array}$ & \\
\hline $\begin{array}{l}\text { Orchard } \\
\text { establishment }\end{array}$ & $2,685.00$ & $11,660.75$ & - & - & $-11,660.75$ \\
\hline Year 1 & $2,020.25$ & $13,681.00$ & - & - & $-13,681.00$ \\
\hline Year 2 & $1,803.25$ & $15,484.25$ & $1,466.96$ & $1,466.96$ & $-14,017.29$ \\
\hline Year 3 & $3,026.00$ & $18,510.25$ & $5,134.36$ & $6,601.32$ & $-11,908.93$ \\
\hline $\begin{array}{l}\text { Full } \\
\text { productivity }\end{array}$ & $4,657.00$ & 23,167.25 & $12,468.80$ & $19,070.12$ & $-4,097.13$ \\
\hline
\end{tabular}

The yield ratio of first-class to second-class pear fruit was $70: 30 \%$ on average, and was accordingly used for revenue calculations across years. Given 
the average farmgate price of $0.5 € / \mathrm{kg}$ for first-class pears and $0.3 € / \mathrm{kg}$ for second-class fruit, the revenue achieved is presented in Table 5.

Table 5 shows that the return on investment in the commercial pear orchard was achieved in the fifth year, along with profit. If the intensive orchard produced a yield higher by 35\% than the average yield projections, as typical of high-density systems, the return on investment would be achieved in the fourth year. At full productivity, the difference between revenue and expenses was $€ 7,811.8$ on an annual basis. Pear production should be based on obtaining firstclass good-quality fruit to generate a higher farmgate price and, hence, a higher value of production. Good-quality pears are mostly exported to foreign markets, particularly to Russia.

\section{Conclusions}

The results of the agroeconomic analysis of establishing a 1 ha pear orchard suggest the following:

- Total orchard establishment and management costs during the first three years are $€ 18,510.25$.

- Orchard management costs at full productivity are €4,657.00.

- The return on investment in a commercial pear orchard, along with profit, is achieved in the fifth year.

\section{References}

Glišić I., Milošević T., Milošević N., Nikolić R., Paunović G. (2014): Agroeconomic analysis of apricot production in early years after planting. Book of Proceedings Fifth International Scientific Agricultural Simposium "Agrosym 2014" Jahorina, BiH, October 23-26, 2014: 215-220.

Milić D., Kalanović-Bulatović B., Veljković B. (2013): Menadžment i organizacija voćarsko-vinogradarske proizvodnje. Agronomski fakultet, Čačak.

Milošević T. (1997): Specijalno voćarstvo. Agronomski fakultet i Zajednica za voće i povrće, Čačak - Beograd: 51-78.

Milošević T., Zornić B., Glišić I. (2008): A comparison of low-density plum plantings for differences in establishment and management costs, and in returns over the first three growing seasons- a mini review. Journal of Horticultural Science \& Biotechnology 83 (5): 539-542.

Mratinić E. (2012): Kruška. Partenon, Beograd.

Trajković S., Milanović M. (2012): Navodnjavanje voćnjaka. Kancelarija za program podrške u privatnom sektoru za podršku sektoru voćarstva i bobičastog voća u Južnoj Srbiji. Niš. 
Acta Agriculturae Serbica, Vol. XXIII, 46(2018); 157-165

\title{
EKONOMSKA ANALIZA PODIZANJA ZASADA KRUŠKE
}

\section{Gorica Paunović ${ }^{1}$, Biljana Veljković ${ }^{1}$, Radmila Ilić ${ }^{1}$, Ljiljana Bošković- Rakočević ${ }^{1}$}

\author{
${ }^{1}$ Univerzitet u Kragujevcu, Agronomski fakultet u Čačku
}

\begin{abstract}
Rezime
Kruška je cenjena, rado gajena voćna vrsta zbog velike upotrebne vrednosti plodova. Poslednjih decenija postojale su velike oscilacije u količini i kvalitetu plodova kruške iz više razloga (zastarela tehnologija gajenja, šarenilo sortimenta, pojačan napad prouzrokovača bakterijalne plamenjače, nestabilno tržište, itd.). Kako u Srbiji postoje povoljni prirodni uslovi, a na domaćem i inostranom tržištu kruška je deficitarna, poslednjih godina raste interes proizvođača za gajenjem kruške. Od uslova tržišta i mogućnosti plasmana kruške zavise u velikoj meri ekonomski rezultati. Pre zasnivanja zasada neophodno je izvršiti sveobuhvatnu analizu agroekonomskih uslova, od kojih zavisi i izbor sortimenta i veličina zasada, pa je cilj rada bio analizirati troškove ulaganja u podizanje zasada kruške. Za ispitivanje su uzete dve sorte Vilijamovka i Santa Maria. Rezultati agroekonomske analize pokazali su da investiciona vrednost podizanja 1 ha zasada iznosi 8975,75€. Troškovi nege zasada u prvoj godini iznose 2020,25€, u drugoj $1803,25 €$, a u trećoj 3026,00€. Ukupno ulaganje u podizanje i negu zasada u prve tri godine iznosi 18510,25€. Troškovi nege zasada kruške u punoj rodnosti su $4657,00 €$. Investiranje u proizvodni zasad kruške otplaćuje se u petoj godini i ostvaruje zarada. Ukoliko bi intenzivni zasad ostvario veći prinos za $35 \%$ od prosečno planiranog, što je odlika proizvodnje u gustoj sadnji investicija bi se otplatila u četvrtoj godini.
\end{abstract}

Ključne reči: Kruška, Ekonomska analiza, Troškovi, Dobit. 